\title{
Innovation Dialectics: An Extended Process Perspective on Innovation in Services
}

\author{
Nardelli, Giulia
}

Published in:

The Service Industries Journal

Link to article, DOI:

10.1080/02642069.2017.1289513

Publication date:

2017

Document Version

Peer reviewed version

Link back to DTU Orbit

Citation (APA):

Nardelli, G. (2017). Innovation Dialectics: An Extended Process Perspective on Innovation in Services. The Service Industries Journal, 37(1), 35-56. https://doi.org/10.1080/02642069.2017.1289513

\section{General rights}

Copyright and moral rights for the publications made accessible in the public portal are retained by the authors and/or other copyright owners and it is a condition of accessing publications that users recognise and abide by the legal requirements associated with these rights.

- Users may download and print one copy of any publication from the public portal for the purpose of private study or research.

- You may not further distribute the material or use it for any profit-making activity or commercial gain

- You may freely distribute the URL identifying the publication in the public portal

If you believe that this document breaches copyright please contact us providing details, and we will remove access to the work immediately and investigate your claim 


\title{
Innovation Dialectics: An Extended Process Perspective on Innovation in
}

\section{Services}

\begin{abstract}
Services are characterized by the involvement of customers and other interest groups in the innovation process. The aim of this study is to understand how and why, in the service context, tensions and potential conflicts between heterogeneous interest groups unfold during processes of innovation. The empirical field in which the investigation was set is facility services, a type of business-to-business support services. The findings were extracted from a longitudinal, in-depth case study of a Danish, multinational organisation over 13 years, complemented with an explorative study in the Danish facility service context. The findings suggest that tensions and conflicts between heterogeneous interest groups are an intrinsic element of innovation processes in services, and that emphasizing them might actually support a clearer understanding of processes of innovation in services. The outcome of the analysis is a process model, which proposes innovation dialectics as one of the driving mechanisms of innovation in services.
\end{abstract}

Keywords: Innovation; Services; Process; Dialectic Processes

\section{Introduction}

In today’s uncertain and fast-moving economic environment, the relationship between supply and demand has evolved. Globalisation and the development of information and communication technologies have amplified competition and introduced increasing complexity to interactions throughout innovation processes (Teece, 2010). Consequently, a larger range of actors can participate in innovation processes, which implies heterogeneity in the needs and expectations that innovators must consider when developing new product and service offerings. This heterogeneity can create inner tensions between the involved actors, which might result in conflicts and thus have a negative impact on the innovation process and its outcomes (see, e.g., Sjödin \& Kristensson, 2012). From the existing literature, we know that innovation processes trigger conflicting demands from different customers, along with contradictory practices among managers and competing views (i.e. tensions and conflicts) among all interest groups (Erez, Jarvenpaa, Lewis, Smith, \& Tracey, 2013; 
van Dijk, Berends, Jelinek, Romme, \& Weggeman, 2011). As the complexity of internal processes makes tensions and conflicts increasingly difficult to deal with, which could either boost or inhibit performance, managers seek to continually improve the management of innovation processes (Erez et al., 2013; Lewis, 2000).

This paper begins by examining the existing research on innovation processes in services, with emphasis on the involvement of customers and other actors. Reaching beyond the collaborative aspects, it is motivated by the importance of addressing the interaction between parties throughout innovation processes in services. Interactions between providers, customers, and other parties have often been presented as collaborative (e.g., Alam, 2002; Bitner, Ostrom, \& Morgan, 2008; Ettlie \& Rosenthal, 2011; Kuusisto \& Riepula, 2011), while tensions and potential conflicts during innovation processes have thus far been overlooked. Presenting collaboration between different parties as a cooperative and straightforward exercise creates a masked, even edulcorated, picture of reality. It limits the theoretical representation of innovation practices, which only considers the positive aspects of such practices, and prevents researchers and practitioners from understanding the many different facets of innovation processes in services. In short, while we know that tensions and conflicts between parties with diverse needs and expectations do arise throughout innovation processes in services, there is a research gap as to how they interact and influence the innovation process itself. Such gap needs to be filled to improve the understanding and enrich the representation of innovation practices in the service context.

By taking the model of the dialectic motor of change by Van den Ven and Poole (1995) as an analytical lens, this paper builds on and contributes to process research on innovation in services. The unit of analysis is tensions and potential conflicts between parties who have diverse needs and expectations and yet interact throughout and are involved in innovation processes (in this paper, referred to as interest groups). The analysis follows the emergent relationship between the development of tensions and potential conflicts and the development of innovation processes over 
time. The data collection and analysis for this study centred on the development of a type of business-to-business support service, that is, facility services, over a 13-year period in a Danish multi-national organisation.

Business-to-business support services, like facility services are responsible for making sure that the employees of the organisation they serve can carry out the tasks and activities related to the core business without having to worry about, for example, the management and maintenance of their workplace or the functioning of information and communication technologies. Furthermore, due to their support nature, in large organisations, it often results in greater economic efficiency to—at least partially_outsource their provision to specialized external providers. When this happens, diverse internal and external actors participate in the innovation processes and bring with them heterogeneous sets of needs and expectations, which might cause tensions and eventually conflicts (Coenen, Alexander, \& Kok, 2013). Because of their supportive nature, facility services are based on a dependent relationship between demand and supply, which characterises them as task-interactive services (Mills \& Margulies, 1980, p. 263). In such services, the interaction between demand and supply is extremely concentrated. The supply needs to satisfy a demand; the demand, in turn, is aware of its needs and expectations, but not able to take care of them itself (Mills \& Margulies, 1980).

Through a qualitative, longitudinal investigation of process data on innovation in services, this study exposes the unfolding of tensions and potential conflicts between the interest groups of a focal entity operating within the context of facility management (FM) services to answer the following research question:

In the context of facility services, how and why do tensions and potential conflicts between heterogeneous interest groups unfold during processes of innovation in services?

The present study addresses the critical issue of the unfolding of innovation processes in services that are unpredictable and made more complex by the involvement of diverse needs and 
expectations. The findings suggest that tensions and conflicts between heterogeneous interest groups are an intrinsic element of innovation processes in service firms, and that emphasizing them might actually support a clearer understanding of such processes. The outcome and contribution of the analysis is a process model, which proposes innovation dialectics as one of the driving mechanisms of innovation in services and which focuses on the emergent yet interactive aspect of innovation itself, something the existing research, until now, has failed to address.

The paper is structured as follows. After having introduced motivation, purpose and scope of research, the theoretical foundations, grounded in research on innovation in services, are presented. A section dedicated to research context and methodology elaborates on the characteristics and reason for selection of the facility service context and discusses data collection and analysis techniques and procedures. Then the longitudinal case study at the centre of this study is described, and findings are depicted following a time-based narrative. In the section dedicated to the Discussion, the answer to this study's research question is proposed by contrasting original findings with existing research on innovation processes in services. Finally, conclusions are drawn, and limitations of the study are outlined along with an agenda for further research.

\section{Theoretical foundations}

According to den Hertog, van der Aa and De Jong (2010), six main dimensions describe a new service: (1) new service concept, (2) new customer interaction, (3) new value system/business partners, (4) new revenue model, (5) new organizational system and (6) new technological service delivery system. Any service innovation involves a certain blend of these dimensions (den Hertog et al., 2010). This study adopts the approach of den Hertog et al. (2010) and refers to innovation in not only new services, but also in new organisational settings, processes, and technologies that provide services (Drejer, 2004). Organisations, and units thereof, are here defined as identifiable entities that develop over time, where development is a change process that unfolds throughout the duration of the entities’ existence (Klarner \& Raisch, 2012). 
The crucial role played by processes in determining the impact of innovation on organisation performance, as well as the success of specific innovation outcomes, was determined through process studies dedicated to the management of innovation in general and in the service context. Building on this stream of research, this paper follows a process approach, as explained in further detail in the methodology section, to uncover tensions and potential conflicts between interest groups involved in service innovation processes. Based on Van de Ven and Poole (1995, 2005), process is here defined as the progression of events in an organisational entity's existence over time; change is defined as a succession of movements in a recognizable entity over time.

\section{Innovation in services: process perspectives}

A systematic literature search on ABI Inform (Webster \& Watson, 2002), scoped to research that investigated process issues within innovation in services, suggested that there is a limited amount of studies on innovation in services that adopt a process approach. Within the process research on innovation in services, two models prevail: (1) the stage-gate, or R\&D-driven model (e.g., Alam \& Perry, 2002; de Brentani, 1991; Scheuing \& Johnson, 1989), and (2) the practicedriven innovation model (Edvardsson, Haglund, \& Mattson, 1995; e.g., Sundbo, 1997). Both models emphasize the innovation process as driven by a specific service provider, but they refer to two opposite modes of change. Stage-gate model researchers postulate that service providers follow (and, if they do not, they should) the example of manufacturers and structure their innovation activities in formalized steps and phases (Alam \& Perry, 2002; Miles, 2008; Ottenbacher, Shaw, \& Ermen, 2006; Scheuing \& Johnson, 1989). The major criticism of the stage-gate model as applied to innovation in services highlights that the model is too strongly grounded in new product development literature and therefore fails to incorporate some of the inner characteristics of services as compared to tangible goods, including the fuzzy distinction between service (and innovation) process and service (and innovation) outcome (Ettlie \& Rosenthal, 2011; Fuglsang, Sundbo, \& Sørensen, 2011; Martin \& Horne, 1993). 
The work by Martin and Horne (1993), on the other hand, launched research on the so-called practice-driven model of innovation, afterwards developed through theory building and inductive methods, aimed at representing the most intangible nature of services. The practice-driven model presents innovation in services as a trial-and-error, overlapping process, where change processes are initiated and managed in response to market opportunities and/or customer dissatisfaction, and only after commercialization, improved and recognized as innovation processes and outcomes (Edvardsson et al., 1995). Nevertheless, research on the practice-driven model also reports systematic practices and strategically driven innovation projects as being typical of services (Edvardsson et al., 1995; Gallouj \& Weinstein, 1997; Sundbo, 1997).

More recent work discusses the issue of involving customers in the service innovation process (Abramovici \& Bancel-Charensol, 2004; Alam, 2002, 2011, 2013; Bitner et al., 2008; Busse \& Wallenburg, 2011; Johne \& Storey, 1998; Kuusisto \& Riepula, 2009; Melton \& Hartline, 2010; Mota Pedrosa, 2012). Scholars have shown potential customer involvement as beneficial to innovation in services, and highlight that customers can be involved through various methods for active and passive contribution, both within stage-gate (Alam, 2002, 2011, 2012, 2013; Bitner et al., 2008) and practice-driven (Ettlie \& Rosenthal, 2011; Kuusisto \& Riepula, 2009) innovation processes. Ordanini and Maglio (2009) present customer involvement not as a tool to improve the management of innovation processes, but rather as a dynamic change process in itself. The decision tree that Ordanini and Maglio propose represents the parallel, interactive, and reciprocal development of change across the service provider, the customers, and the external interest groups, such as suppliers and competitors (Ordanini \& Maglio, 2009). Similarly, Fuglsang et al. (2011) and Matthing et al. (2004) present models of practice-driven and interactive innovation—structured innovation processes—but not necessary sequential, and most importantly, open to external inputs.

The opening towards interactive processes offers a broader understanding of innovation as compared to stage-gate and practice-driven models, which describe innovation processes as mono- 
directionally driven by the service providers. Nevertheless, the process of collaboration for innovation has often been presented as a rather prescribed unfolding of relationships. When it comes to investigating interactive, multi-dimensional and unplanned processes of innovation in services, scholars have mainly emphasised the perspective of the innovator (e.g., Barras, 1990; Edvardsson \& Olsson, 1996; Flikkema, Jansen, \& Van Der Sluis, 2007; Ordanini \& Maglio, 2009). Only three studies to date have stressed how, in the service context, the innovation process develops on a track parallel to customer involvement, driven either by the service process or the customer process, depending on how structured and systematically the innovation process is managed (Edvardsson \& Olsson, 1996; Flikkema et al., 2007). Chae (2012) goes a step further and conceptualizes innovation in services as an evolutionary process that takes place in multiple innovation and customer involvement processes. The motor of innovation is here described as interactive, local, multidimensional, unpredictable, and emergent (Chae, 2012).

Therefore, it is known that (1) processes of innovation in services can involve multiple parties with needs and expectations (Abramovici \& Bancel-Charensol, 2004; Alam, 2002, 2011, 2013; Bitner et al., 2008; Busse \& Wallenburg, 2011; Johne \& Storey, 1998; Kuusisto \& Riepula, 2009; Melton \& Hartline, 2010; Mota Pedrosa, 2012); (2) processes of innovation in services have a predictable side, and can therefore be structured and planned (Alam \& Perry, 2002; Miles, 2008; Ottenbacher et al., 2006; Scheuing \& Johnson, 1989), but also have an unpredictable and emergent side (Ettlie \& Rosenthal, 2011; Fuglsang et al., 2011; Martin \& Horne, 1993); and (3) both predicted and unpredicted processes of innovation in services unfold when the needs and expectations of the parties involved are aligned (Alam, 2002, 2011, 2012, 2013; Bitner et al., 2008; Ettlie \& Rosenthal, 2011; Kuusisto \& Riepula, 2009). What is lacking is the understanding of how processes of innovation in services unfold when multiple parties with non-aligned needs and expectations are involved, that is, when tensions and conflicts between interest groups arise. 
Processes of change, such as innovation, are complex and continuous events, and are difficult to fully understand due to their multiple facets. To simplify such complexity, Van de Ven and Poole (1995) suggest breaking down change processes according to the motor that drives them and propose a typology with four distinct motors of change. Each motor offers a single perspective from which to examine the change and innovation processes (Figure 1). In other words, the typology is meant to integrate different perspectives on organisational change, and is based on two dimensions: (1) the unit of change, that is, single or multiple entity/entities, and (2) the mode of change, that is, prescribed or constructive.

Figure 1 near here

A prescribed mode of change channels the development of entities in a pre-specified direction, typically for maintaining and incrementally adapting their forms in a stable, predictable way. On the other hand, a constructive mode of change generates unprecedented, novel forms that in retrospect are often discontinuous and unpredictable departures from the past. It thus produces new action routines that may or may not create an original reformulation of the entity (Van de Ven \& Poole, 1995).

Van de Ven and Poole (1995) stress that their typology does not present four independent motors, but rather four dimensions of change within an organisation. The distinction between the four motors allows simplification of the complex reality of change processes, whereas ideally, to fully understand a specific process of change, such as innovation in services, all four motors, and combinations thereof, should be explored (Van de Ven \& Poole, 1995). If Van de Ven and Poole’s (1995) approach is followed, we should get a complete overview of innovation processes in the service context by combining the four motors of change that characterise innovation in services. However, existing research on innovation processes in services, despite recognizing the role of the involvement of customers and other interest groups, fails to look at how processes of innovation in services unfold when multiple parties with contrasting needs and expectations are involved. 
Building on existing literature within the service context on innovation processes where emergent change is brought about by multiple units of change (i.e., Chae, 2012; Edvardsson \& Olsson, 1996; Flikkema et al., 2007), this study investigates innovation processes in services through the lens of the dialectic motor (Van de Ven \& Poole, 1995) to uncover a critical aspect of innovation in services, which is still under-researched and poorly understood, yet crucial for obtaining a more thorough overview of innovation in services. This model is therefore applied to a variety of innovation processes in services in this study, to emphasise tensions and potential conflicts among heterogeneous interest groups. Dialectic processes describe the sequence by which the thesis and anti-thesis confront and engage each other in a conflict struggle. Events leading to confrontation of opposites and resolutions may occur intermittently over the course of development, and the result of the conflict is a synthesis that breaks the current frame and typically produces a revolutionary change (Van de Ven \& Poole, 1995).

\section{Innovation processes in the empirical context of facility services}

In the last three decades, facility services have established themselves as a key service sector, despite their traditional role as a supporting set of activities as compared to the core business of the organisations they serve. The facility service sector is characterised by a diverse and highly competitive market of contractors, in-house and outsourced providers, consultants, and professional institutions (Cardellino \& Finch, 2006), implying heterogeneous supply chains (Nutt, 2000) and value networks (Coenen et al., 2013).

Facility providers have often demonstrated the dedication and drive to implement new service development, and even exceed customer expectations, when adding value to their client organisations (Mudrak, Van Wagenberg, \& Wubben, 2005; Pitt \& Tucker, 2008). Facility service organisations are thus not only able, but also do manage innovation as a process. In fact, they tend to have several projects under development at the same time. However, they struggle to establish innovation routines that enable successful innovation management in the sense of systematic new 
service development (Cardellino \& Finch, 2006; Mudrak et al., 2005). Goyal and Pitt (2007), specifically, stress the need for all interest groups to be involved and cooperate during innovation processes to manage the diverse interactions that characterise facility services. Similarly, Noor and Pitt (2009) argue that a collaborative and partnership approach to innovation is crucial for bridging demand and supply (whether in-house or outsourced) of facility service delivery by building an innovation network with all involved actors. Yet, facility service literature lacks emphasis on the demand side of innovations (Coenen et al., 2013) and as for what concerns innovation processes, only the life-cycle motor (Cardellino \& Finch, 2006) has been considered thus far.

\section{Research context and methodology}

\section{The process approach and theory building from case study research}

To address innovation in services, this study follows a process approach, which allows the exploration of the unfolding of tensions and potential conflicts among heterogeneous interest groups during innovation processes. To ensure a systematic approach to process conceptualization, the process methodology by Langley et al. (2013) was combined with some of the research tools depicted by Eisenhardt (1989) to guide theory building from case study research. First, a structured literature review was carried out to (1) build the grounds of the investigation; (2) identify the research objective; and (3) specify the a priori constructs (Eisenhardt, 1989). The empirical context for the investigation was then selected, and the field was approached through the techniques and procedures for data collection and analysis as described in the following paragraphs.

\section{The empirical context: facility services}

The empirical context of facility services has been selected as a valid and appropriate field in which to investigate the research question for four main reasons. First, innovation plays a significant role when it comes to the value that facility services adds to the core business of the organisation they serve (e.g., Jensen et al., 2012). Second, the decision-making process in facility services is characterised by high complexity due to the continuous emergence of specific problems, needs, and 
expectations, which require novel solutions (e.g., Coenen et al., 2013; Jensen, 2008). Third, the diversity of internal and external interest groups makes facility services a relevant and critical case (Yin, 2009) in which relationships and exchange dynamics between parties are crucial elements of development and change. Finally, in facility services, interactions, and more specifically tensions and conflicts between parties, are transparently observable, as diverse interest groups appear to have characteristics, needs, and expectations that are similar within groups, heterogeneous between groups, and yet comparable across different cases (Coenen et al., 2013). For these reasons, facility services that are partially or totally outsourced to external providers were selected for this study, among other business-to-business support services, to investigate the unfolding of innovation processes in services that involve tensions and conflicts.

\section{Data collection}

Qualitative research methods were chosen for this study as they correspond well to a perspective emphasizing process questions and to processes rather than variables as the primary focus of attention (Rasche \& Chia, 2009). Longitudinal, rich, and varied process data were collected through both interviews and archive data (Bohnsack, Pinkse, \& Kolk, 2014; Geels, 2002; Lehoux, Daudelin, Williams-Jones, Denis, \& Longo, 2014), while longitudinal data are necessary to observe how processes unfold over time, and archive data support interview data for tracing event chronologies, meanings, and discourses over long periods of time (Langley et al., 2013). Overall, the data collection included an explorative study and a longitudinal case study over 13 years (Table 1). The interviews were carried out in English and transcribed ad verbatim to preserve the language, phrases and expressions used by the interviewees themselves. Please notice that in accordance to the confidentiality agreement with the organisations involved in the study, only quotes from the interviews (and not from the archive data) are reported verbatim in this paper.

Table 1 near here 
The selected population is the Danish field of facility services to control for environmental variations and clarify the domain of findings as facility service (internal and outsourced) providers (Eisenhardt, 1989). Theoretical sampling in the course of the research (Eisenhardt \& Bourgeois, 1988) was carried out in two subsequent phases. First, an explorative study (Miles \& Huberman, 1994) was conducted in the context of Danish facility services. In this phase, convenience sampling was used at first, and then progressed to snowball sampling (Eisenhardt, 1989) to ensure variety and to overcome network limitations in the initial phases of the investigation. The explorative study allowed the collection of interactional expertise, which helped the researcher to relate to specialized practitioners and better understand the general ways of dealing with change and innovation processes (Langley et al., 2013). Such preliminary investigation was aimed at shedding light on innovation processes within the context of FM services, and more importantly, at theoretically sampling a critical case where tensions and conflicts between interest groups involved in innovation processes in services were observable (Eisenhardt, 1989).

Theoretical sampling, specifically, was intended to support the choosing of cases that were likely to replicate or extend the emergent theory, and not to obtain statistical evidence. Hence, the findings of this study aim for generalizability (Lee \& Baskerville, 2003), or given the nature of this empirical work, versatility (Poole, Van de Ven, Dooley, \& Holmes, 2000). Versatility is the degree to which an explanation and/or theory can include a broad domain of context without modification of its essential character (Poole et al., 2000). In other words, a versatile process explanation and/or theory can stretch or shrink to fit specific cases in various contexts and at different points in time (Van de Ven \& Poole, 2005). Rather than being generalizable in statistical terms, the overall results of this empirical research can be considered versatile. More specifically, versatility was aimed for during the whole research process (1) by using theoretical sampling; (2) through a systematic approach to data collection and analysis aided by using Atlas.ti; and (3) by extensively describing the methods for data collection and analysis so that other researchers could replicate the research process 
(Corbin \& Strauss, 2008; Eisenhardt, 1989; Glaser \& Strauss, 2009). Throughout the years, such guidelines have been accepted as reliable for achieving generalization from empirical descriptions to theory (Lee \& Baskerville, 2003), which is why they were followed here.

After the explorative study, the unit of analysis, that is, tensions and potential conflicts between heterogeneous interest groups, was investigated within the development of facility services as provided by the internal facility service unit of a Danish multi-national organisation. The organisation for the longitudinal case study was selected among those involved in the explorative study due to its focus on innovation within both the core business and the supporting facility services. Not only has the selected entity been characterised by a process of continuous change in multiple aspects since its foundation, but the managers in charge have also demonstrated a peculiar interest in a planned and structured management of innovation processes in facility services. This characterises the selected organisation as a relevant and critical case, and made it possible to investigate innovation processes that were both planned and emergent. The service provider under investigation was examined over a time period of 13 years. The longitudinal perspective allows for examination of the relationships and exchanges—and therefore tensions and conflicts—-between interest groups during innovation processes at different stages of organisational development (Drori \& Honig, 2013). In addition, such a research setting is attractive because it allows, within the development of the facility service provided by the facility service unit, the investigation of multiple processes of innovation of diverse natures and causes that occurred between the same set(s) of interest groups.

The case study design can be defined as embedded (Guerard, Bode, \& Gustafsson, 2013; Yin, 2009) as, to increase the number of theoretical observations and thereby enable the identification of specific theoretical mechanisms associated with innovations in services that would recur over time, temporal bracketing (Langley, 1999) or decomposition (Langley et al., 2013) was applied. Within the stream of longitudinal data from the main case study, four main instances of tensions and/or conflicts 
between interest groups that were intertwined with the innovation processes were identified. These temporal brackets (de-merge crisis; financial crisis; global shift; organisational change) are constructed as progressions of events and activities that are separated by identifiable discontinuities in the temporal flow (Langley et al., 2013). The critical incident technique was used to spot such discontinuities and determine the most appropriate temporal brackets (Gremler, 2004). Researchers have used the critical incident technique primarily in business-to-consumer contexts, although its characteristics make its use also appropriate in a broader range of issues (Butterfield, Borgen, Amundson, \& Maglio, 2005; Gremler, 2004), such as the cross-organisational context investigated here. Each temporal bracket identified in this study represents an instance (critical incident) of innovation process because they all imply a change in one or more of the dimensions of innovation as defined by den Hertog et al. (2010).

The data collection aimed at shedding light on the development process of the facility service provision under investigation and related interest groups, and combined data mining with in-depth, semi-structured interviews of 45 to 90 minutes with the main representatives of the internal facility management unit and of the main external provider (Table 1).

In accordance with the critical incidents technique, respondents were explicitly asked to elaborate on the issues that arose during the interviews, with emphasis on those events that made a significant contribution, either positive or negative, to the activities or phenomena being discussed (Butterfield, Borgen, Amundson, \& Erlebach, 2010; Gremler, 2004; Specht, Fichtel, \& Meyer, 2007). More specifically, once a respondent mentioned an event that he or she identified as critical, four elements were discussed and documented: (1) the time the incident occurred; (2) a description of what happened; (3) the reasons behind the occurrence of the incident; and (4) the outcome of the incident (Ahola, 2009, p. 88).

Once the main critical incidents, and thereby the temporal brackets, were identified, the interviews aimed at shedding light on the various aspects, events, and innovation processes that 
occurred during each period. To avoid memory bias (Eisenhardt, 1989), to identify the dates of the critical incidents with greater precision, to enrich the database, and to inform the semi-structured interviews (Langley, 1999; Yin, 2009), the interviews were complemented with archival data mining (Guerard et al., 2013) on the development of the facility service unit. The archive data for the longitudinal study (22 documents, e.g., presentations, strategy plans and evaluations, toolbox, meeting minutes, project proposal, benchmarking reports) were collected in three sessions throughout 2013. During these sessions, the director and a senior manager of the unit, who were directly and actively involved in the processes under investigation, led the data mining by opening up and going through their database with the researcher and extracting and linking all sets of data that were linked to the activities and processes described during the interviews.

\section{Data analysis}

Throughout the whole research process carried out for this work, data analysis has overlapped data collection (Eisenhardt, 1989). In the present study, first, field notes were taken through interview reports and memos during and after the explorative interviews and other encounters with facility service practitioners, for example, at seminars and conferences. Second, flexible, yet systematic data collection was implemented throughout both the explorative and the in-depth case studies, which was aimed at a solid foundation for the construction of the theory. Interview protocols were adjusted during data collection on the basis of the emergence of interesting themes. The initial plan for the sourcing of data was also modified by adding in-depth interviews in cases where the explorative study highlighted similar or contrasting evidence that was relevant to the main case (Eisenhardt, 1989). Finally, a database was built to incorporate field notes, verbatim transcripts of the interviews, and archive data.

To aid the data analysis, the software Atlas.ti, v.6, was used. The database (60 files in total) was transferred into the software, and several steps of line-by-line, open and axial coding were carried out. The analysis of the data was inspired by Langley's (1999) strategies for theorizing from 
process data, and used narratives both for the within-case analysis and the following cross-case analysis (Eisenhardt, 1989). Eisenhardt (1989) warns against the risks of poor information processing and suggests applying a structured and diverse approach to cross-case analysis. For this study, (1) categories and dimensions in the data were selected to look for within-group similarities and intergroup differences; and (2) pairs of periods were extracted and searched for similarities and differences (Eisenhardt, 1989). To strengthen internal validity, ensure relationship consistency within and across temporal brackets, and abstracting from the particular to the general, open and axial coding was based both on the constructs emerging from data and on those derived from the existing literature (Langley et al., 2013).

Finally, for reaching closure in the study, Eisenhardt's (1989) guidelines were combined with those by Langley et al. (2013). In the explorative study, data collection concluded when theoretical saturation was reached, that is, as incremental learning on the processes that were being investigated was minimal. In the in-depth case study, four periods were developed from temporal bracketing, and data collection on the processes was terminated for a combination of pragmatic considerations (issues related to time and financial resources) and saturation, that is, the last interviews did not offer significant contributions to the emergent theory on value co-creation processes. Moreover, the iteration between data and theory was interrupted when saturation was reached, that is, when additional literature did not further significantly contribute to the emergent theory (Eisenhardt, 1989; Langley et al., 2013).

\section{Findings}

The facility services whose innovation processes were examined in this study, are those provided to Novozymes, a Danish, multi-national organisation (6,200+ employees). The core business of Novozymes lies within industrial biotechnology, with a strong focus on enzyme production (Novozymes, 2013). The set of interest groups under investigation includes: (1) the developing internal facility service unit, heretofore also referred to as NZ FM (Novozymes Facility 
Management, i.e., its acronym and name within the organisation); (2) the organisation, heretofore also referred to as NZ, which is supported by such unit; (3) its employees, who are served by NZ FM; and (4) the outsourced providers.

The analysis of the focal case starts in 2000, when Novozymes de-merged from its mother company, Novo Nordisk. The intertwining of tensions and conflicts between Novozymes' interest groups and the innovation processes carried out in their network developed over time and went through four critical phases or temporal brackets: (1) a de-merge crisis; (2) a financial crisis; (3) a global shift; and (4) an organisational change. As previously mentioned, this study examines innovation in services as a combination of new services, and the new organisational settings, processes, and technologies that allow the service provision (den Hertog et al., 2010; Drejer, 2004); each bracket in the case is characterised by innovation processes and outcomes as stressed at the end of each sub-section below. Table 2 summarises and organises the findings derived from the case of Novozymes by critical incidents. As the focus of this study is the dialectic aspect of innovation processes in services, the table highlights the thesis, anti-thesis, conflict, and synthesis of each bracketed change. Moreover, it points out the innovation outcome(s) and the impact on the different interest groups of the processes studied.

Table 2 near here

\section{The de-merge crisis}

When Novozymes de-merged from its mother company, it shortly realized that it needed to determine how to deal with facility services, which were previously taken care of by the facility service unit of the mother company. An embryonic FM unit was created, composed of only a director from the Purchasing unit, who could initially only dedicate $20 \%$ of his time to ensure that facility services were allocated efficiently to the employees. Soon after the de-merge, he had to re-negotiate the contract with the outsourced provider, and together with Novozymes’ executive management, 
decided to discontinue the existing relationship to obtain better conditions, such as greater transparency, cost competitiveness, and better services.

We were negotiating a new agreement and they (the outsourced provider, ed.) told us that we should look at the new agreement they had written for us, and we couldn't change it. And we had one week to decide if we accepted that agreement or not. (31:10-11; interview with FM director)

A major conflict arose as the decision to discontinue the relationship caused the refusal by the former external facility service provider to share any information and/or data about the past facility service provision with the embryonic facility service unit. This meant that the latter had to start from scratch to determine how to ensure that employees could carry out the activities related to the core business without noticing the on-going shift of providers. This conflict caused the threat of a mismatch between the needs and expectations of NZ and its employees and the needs and expectations of the embryonic facility service unit, and thus of a potential conflict between interest groups. On one hand, the employees expected (and were expected by Novozymes' executive management) to be able to conduct core business activities as usual. On the other hand, the embryonic facility service unit expected (and, yet again, was expected by Novozymes’ executive management) to ensure the best possible deal for Novozymes in terms of transparency, low cost, and dedicated services.

We didn't get any help from out former supplier and if we wanted any documentation, we should have paid for it... So we said 'Ok, keep your information, we build it up from the beginning... And some of the services were critical issues, because we did not know anything about it, and that could [hit hard on] our R\&D (ed.)... (31:12; interview with FM director)

The facility service manager and the executive management acknowledged the potential mismatch, and yet proceeded to discontinue the contract with the external provider. The goal now was to find new facility service providers who would be able to ensure the functioning of the core business at the lowest possible expense-as well as satisfy the needs and expectations of the employees.

We didn't know exactly who was the supplier and what was the cost... We ranked different areas and different focuses, and talked [about] how we should handle that (ed.)... If you go back to 2005, there was not a strategy, it was damage control... (31:11-12, 29; interview with FM director) 
In addition, significant effort was invested into designing and implementing a communication strategy that would explain the on-going changes to Novozymes' employees, thereby limiting dissatisfaction and related tensions with the newly appointed internal and external facility service providers.

In this first temporal bracket, the innovation process under investigation is the change in the provision, organisation, and management of facility services, beginning with the de-merge from the mother company. The outcome of such change was the new client interface that all four interest groups, although they experienced different impacts, had to deal with from that moment on (see the Period I column of Table 2). The innovation process originated a new set of facility services (novel in their composition and characteristics due to the new outsourced providers), organisational settings (novel due to the collaborative relationship established with the new outsourced providers), and processes (novel due to the focus on cost competitiveness and transparency).

\section{The financial crisis}

Once the initial challenges were faced and external providers selected, NZ FM became an actual independent unit reporting to the vice president of Stakeholder Relations. The director from Purchasing, who led the process from the time of the de-merger, was appointed director of the FM unit and new managers were hired.

The newly formed facility service unit was responsible for a limited amount of facility services (real estate; technical maintenance and renovation; cleaning and catering; logistics) at Novozymes' headquarters in Denmark, while the other FM services (and those in other NZ sites around the world) continued to be managed by 'regular' employees within the local units, based on specific needs and personal preferences.

In the production (...) maybe they should focus on what is the core business of production. And that's definitely not to take care of building maintenance, even if they could do it. (55:18; interview with FM director)

The more NZ FM developed, the more sophisticated became the needs and expectations of the organisation as a whole and of the employees with regards to facility services; they moved from 
the operational to the tactical and strategic levels. While an increasing number of facility services were assigned to the NZ FM unit, an exogenous shock hit Novozymes—-the financial crisis. When the financial crisis reached Denmark, Novozymes’ executive management asked that the budget for service provision to the facility unit be reduced.

\footnotetext{
One of the trends we saw very early in the regression of the financial crisis, was that space usage became important to focus on: how could we avoid disagreements outside our building portfolio, how could we optimize space usage primarily in the office buildings that we owned, to avoid costs. (53:6; interview with DK FM manager)
}

The exogenous shock introduced to Novozymes with the financial crisis generated a mismatch between the expectations of the employees, who were used to high level services, and the needs of the executive management, which turned its attention to facility services as a potential source of cost savings. One of the side projects, which originated in connection to the financial crisis, was the reduction of travel expenses. Novozymes is a multi-national organisation, which implies that its employees are often required to travel within and outside of Europe. However, with the financial crisis hitting Denmark and Novozymes, a new travel policy was implemented that included a plan for implementing new information and communication technologies to reduce traveling. The NZ FM unit therefore became involved in the development and implementation of videoconference rooms, which offer a realistic meeting experience, and have thus supported a significant reduction of travelrelated costs as well as a decrease in individual employee annoyances, such as jet lag. While the facility service unit was not directly responsible for the project, it was involved in the innovation process related to it. NZ FM cooperated with other internal units to find the best possible solution to ensure a balance between the needs of the employees and those of the executive management. While the videoconference solution is not a substitute for personal communication, it offers an innovative and satisfactory experience that ensures a balance of needs and expectations between the involved interest groups.

People want to meet face-to-face, and if they see that they can meet face-to-face in a very efficient way with these technology solutions, maybe they are less keen on traveling abroad and using lots of time and money on traveling. And in fact that worked very well. People are very happy to use tale-presence technologies and not just traveling to the US for a meeting or two.

(53:25; interview with DK FM manager) 
The innovation process bracketed within Period II was triggered by the impact of the financial crisis on the Danish economy, and brought about new technological options that substituted for the traditional provision of facility services. In this case, we see a change that culminates in the adoption of new technologies and the consequent change in the travel policies of Novozymes. Again, the interest groups experienced the change and its outcome differently and had to adapt their needs and expectations to the novel status quo (Period II column of Table 2).

\section{The global shift}

By 2009, NZ FM was composed of a team of facility service managers led by a facility service director, who operated at the Danish level and reported to the vice-president of Stakeholder Relations. Other than managing facility services in the best possible interest of the employees, NZ FM started working on the development of some 'transparency tools' that would ease communication with executive management. The goal of transparency had been one of the major drivers of NZ FM development since the time of the de-merger, with the aim of achieving a better quality-cost ratio for facility services. In addition, transparency would support better communication with the executive management, which in turn would result in increased awareness of the potential contribution that facility services could offer to the core services.

\footnotetext{
Our executive vice-president learned that we could create this transparency, that we could boil all these excel sheets and work orders and energy invoices and all that (...) and create some understanding of what's important, what's to be prioritized, where should we pull money, and put money (...) so it was very much easier for him and his leader group (i.e., the group of executive managers he was working with, ed.) to make the right decision on how to spend FM money the right way. (30:20; interview with DK FM manager)
}

The idea of extending the responsibilities of NZ FM outside the Danish sites and building a facility service unit to manage facility services on a larger scale (in other NZ sites around the world) was initiated once the executive management realized the potential of proper management of facility services. With the aid of academic facility service research, a knowledge sharing exercise was conducted with 10 other Danish multi-national companies to explore how facility services could be managed. Two main dimensions were investigated: (1) centralisation, and (2) globalisation. 
We interviewed 10 big global Danish companies, and based on that we went to our executive management, and [we] presented what are the other companies doing (ed.) (...). Based on that we got a mandate to start a project to see if we should start a global organisation. (55:2; Interview with FM director)

Knowledge sharing provided the inspiration for a globalisation project, which was called Global Facility Management (GFM), initiated in 2011. The GFM project was launched to identify the similarities and differences between facility services in Denmark and those around the world. The emphasis was not only on the facility services themselves, but also on the needs and expectations of local employees and executive management, along with the cultural differences in people’s behaviour, rules, and regulations.

The plan for a global organisation carried the risk of creating an imbalance between the satisfaction of local employees and the goals and objectives of the centralised management. Such risk was dealt with by creating a team of internal facility service managers from the different sites interested in the project to map local needs and expectations and compare them with the potential global requirements and standards. Since the team was located at different sites, the facility service managers kept in touch through videoconferences, telephone calls, and quarterly meetings that allowed them to keep a grip on the local interests while they attempted to establish a common strategy.

\footnotetext{
So building maintenance was one large IT challenge, space management the highest priority, and the third challenge was when we started the GFM through and had to invite all our colleagues to discuss how should [the] facility service[ unit] perform in NZ (ed.). Communication was very important. (53:8; Interview with DK FM manager)
}

The third bracket that emerged from the case study is the one associated with the global shift due to the decision to centralise and globalise the provision of facility services. The outcome of this particular innovation process was a new service delivery system grounded in the balance between specialisation and standardisation of facility services on a global scale. While the tension between local managers and global interests characterised the unfolding of the innovation process, the interest groups impacted by the change were the organisation as a whole, NZ FM, and NZ employees. The first group began seeing benefits due to increased transparency; the second gained global 
responsibilities; and the third faced different standards in terms of the facility services provided (Period III column in Table 2).

\section{The organisational change}

In April 2013, the CEO who had led Novozymes since the 1990s, retired, and the new CEO introduced several organisational changes immediately. Some of these changes had a direct impact on NZ FM and the provision of facility services. First, the new organisational structure put NZ FM together with all other support services under the responsibility of the vice-president of Global

\section{Business Services.}

We got a new CEO... What he did was to put an organisation in place, which is more flexible... He decided to take away all these 'non-core' activities, functions, responsibilities, and put them into corporate functions... We are at the moment on a journey to provide NZ with the right services together with other corporate functions... It was decided to create a 'global business centre’ or business service unit, led by a vice-president. (56:2; Interview with ROTW FM director)

Second, the facility service unit was divided into two entities led by two facility service directors: one responsible for Denmark (DK FM), and one for the Rest-Of-The-World (ROTW FM). The goals and objectives of the GFM team were transferred to the newly formed ROTW FM unit, which basically had to define the scope of its service provision from scratch.

We are going to have resources; we are going to have dedicated support from the rest of the global functions to run and drive our way forward. (56:3; interview with ROTW FM director)

The organisational change thus created a mismatch between the needs and expectations of the executive management and the newly reorganised facility service institution, and those of the employees. On one hand, the novel ROTW FM unit is grounded in the strategy and ambition to develop a facility service organisation built on strong efficiency and global standards. On the other hand, the employees all around the world are used to the decentralised management of facility services, which implies that there is greater attention being paid to individual requests at the expense of efficiency.

We need to optimize what we are doing, we need to standardize and we need to be better to predict and to be at the right place in the right time. (...) There is not yet a red line (common thread, ed.) for going through how we do stuff. (...) And we need to map these; we need to be in control. (...) It is not only about a global footprint, it’s also about getting in control locally! (...) 
Every time somebody needs a new chair, needs to paint or wants to increase our security, they go to her (a local FM manager, ed.) and she fixes it. (56:7; Interview with ROTW FM director)

However, the goal of the new setup is not only to reduce costs, but rather to improve the global provision of facility services to ensure a balance between the needs and expectations of the organisation as a whole and the end-users, wherever they are located around the world, which means that differences between local sites need to be considered and adjusted to the local reality when developing and implementing global standards.

In the meantime, DK FM has focused on the original goals-transparency, improved efficiency, and improved quality/cost ratio—-to maintain continuous development. Having managed to establish a solid balance between the needs and expectations of different interest groups at the operational level, DK FM has begun a process to identify the potential additional areas of contribution to the core business. For instance, one of the current issues on which DK FM is working is improvement of workspaces based on (1) the availability of resources by the client organisation; and (2) the need and expectations of the end-users, for example, how much time employees spend in their offices as opposed to meeting rooms. The DK FM unit is therefore participating in a benchmarking program with other Scandinavian organisations, led by a specialized facility service consultant, to (1) map and evaluate the needs and expectations of its internal interest groups and related levels of satisfaction; and (2) be inspired as to how similar or contrasting needs and expectations are managed in other environments for further potential developments.

This fourth period addresses an innovation process that is characterised by an organisational change and resulted, once again, in a new service delivery system. The globalisation of the facility service organisation had, at this point, gone along with the one at Novozymes itself and the tensions between local and global interests arose once again (Period IV column in Table 2).

\section{Innovation dialectics as driver of innovation processes in services: a dialectic process model}

A recurrent finding across the observed innovation processes is that, although the different interest groups tend to have a specific role and be positioned on a specific level within the 
organisation, when a change caused either by exogenous shock or endogenous decision is introduced into the system, they often faced with the needs of other parties. As a consequence, each interest group set must deal with issues, needs, and expectations that belong to a different level. This causes tensions between interest groups, all of whom want to have their needs and expectations satisfiedeven at the expense of other interest groups (although this is not always the case). In turn, such tensions trigger a dialectic motor of change, which is here called innovation dialectics. Building on Van de Ven and Poole (1995), innovation dialectics is defined as a constructive mode of change that takes place within a network of two or more interest groups, and that generates a break with the past basic assumptions that regulated their relationship. As introduced above, Table 2 illustrates the functioning of the dialectic motor of change in the case of Novozymes.

As shown in Table 2, in the case of NZ FM, development and related service innovation thesis and anti-thesis are respectively (1) new needs and expectations of one (or more) set of interest groups, originating through the introduction of a change into the system; and (2) existing needs and expectations of other interest groups. The conflict is the mismatch of needs and expectations resulting from the confrontation of diverse interest groups, which eventually resolves in synthesis. The arrow in the table represents the new status quo that each synthesis represents in the next period. Only one arrow is visualized here to keep the table readable, but there are meant to be three, each representing a synthesis feeding into the next period.

Zooming into (Langley, 1999; Langley et al., 1999) innovation processes for new or improved single services highlights the same mechanisms; for instance, when NZ FM began its activities as a formalized unit, the team realized that the employees' need for meeting rooms was not completely satisfied in the current setup. However, budget and space restrictions (the needs of the organisation as a whole) did not allow for the offering of additional rooms, which caused tensions and a potential conflict between Novozymes' executive management and NZ employees. The synthesis of the mismatch, that is, the attempt to create a balance between such needs and 
expectations, consisted of an innovation in the space management service provision- the development of a walk-and-talk path as meeting room alternative.

We started sending out newsletter... and (the end-users requested, ed.) 'We want some new meeting areas, and more meeting rooms'. Because we did not have so many meeting rooms as we needed, we proposed people to meet in the reception and we arranged some walk-and-talk routes. So if they wanted to have a green area they could be in the nature, or shortly walk around the buildings so and so many times... and people have been very fond of that. (55:10; Interview with DK FM director)

Based on these findings, a process model of innovation in services centred on the dialectic motor of change and driven by innovation dialectics is proposed (Figure 2).

Figure 2 near here

In this process model, innovation dialectics are triggered by change, which can originate from an exogenous shock coming from outside the network of interest groups or from an endogenous decision by one of the parties involved. Endogenous change is here defined as a change that originates within the focal interest group network and is directly linked to the decision making for the innovation processes under investigation, such as the decision to discontinue an agreement with existing suppliers. Exogenous shock, on the other hand, is a change originating outside the focal network that cannot be controlled by the interest groups and is not directly linked to the innovation processes under investigation, for example, the financial crisis. The change of CEO, for instance, could be considered an exogenous shock as it was independent from the decision making of the interest groups involved in the innovation processes related to facility services; these groups had to accept the organisational changes that the new CEO implemented and deal with the related consequences.

When change is introduced into the system, innovation dialectics kick in as new needs and expectations (of one or more interest groups) confront the existing ones. The mismatch of needs and expectation, in turn, results in an explicit or implicit conflict, which is resolved by re-balancing the interests of the various parties. Finally, the synthesis feeds back into the process, as (1) a new status quo for some interest groups (dashed line in figure 2) and as (2) endogenous change for others 
(dotted line in figure 2). In the model, innovation dialectics are represented by the large arrow, as they are intended as a transition, not a status, through which heterogeneous interest groups drive innovation processes through the tensions and conflicts originating from their mismatched needs and expectations. The succession and combination of various episodes of innovation dialectics are what constitute the innovation process and contribute to eventual innovation outcomes.

\section{Discussion}

This study is centred on the research question: How and why do tensions and potential conflicts between heterogeneous interest groups unfold during processes of innovation in services? In this section, the proposed answer to this question is outlined by presenting the findings just illustrated in relation to the existing literature on innovation processes in services.

\section{The unfolding of tensions and conflict during innovation processes in services}

The longitudinal analysis of the development of the facility service provision at Novozymes over time allowed for the identification of patterns across various processes and dimensions of innovation in services. These common patterns reflect the driving role that tensions and conflict between interest groups plays with regard to innovation processes that are here represented by the construct innovation dialectics. At the same time, the data indicate that the trigger of tensions and conflicts might derive either from an exogenous shock, on whose impact the interest groups has no control, or from an endogenous change, which might actually be derived from a previous episode of innovation dialectics.

Early literature on innovation in services identified the potential tensions that might arise among innovation process interest groups (Sundbo, 1997). Later, research on process innovation in services developed two main streams of thought. On the one hand, some scholars built on new product development models and proposed formalized and structured processes as the way to develop new services and improve existing ones (e.g., Alam \& Perry, 2002; de Brentani, 1991; Scheuing \& Johnson, 1989). On the other hand, the intangible nature of services was taken under 
stronger consideration and practice-driven processes arose (e.g., Edvardsson et al., 1995; Gallouj \& Weinstein, 1997; Martin \& Horne, 1993; Sundbo, 1997). What both streams failed to consider is the emergence of tensions and conflicts between the heterogeneous interest groups of innovation in services despite the increasing significance of customer involvement. This study contributes to the theory on innovation in services as it suggests that tensions and conflicts unfold along with innovation processes as every step that is carried out constitutes an upset to the status quo, which, in turn, might originate a mismatch between the needs and expectations of the interest groups. Although further studies are needed to test how innovation dialectics interact with stage-gate and practicedriven innovation processes, the findings from this study suggest that there is more to innovation in services than a combination of planned and emergent changes, that is, that innovation dialectics is a driver of innovation as well as the entrepreneurial initiative of innovators (e.g., Alam, 2002; Miles, 2008; Scheuing \& Johnson, 1989) and the trial-and-error response to market opportunities and/or customer dissatisfaction (Edvardsson et al., 1995; Fuglsang et al., 2011; Martin \& Horne, 1993). It thereby enriches our understanding of innovation in services by highlighting that stage-gate and practice-driven models are only one side of the picture and suggests that further research is needed to fully uncover innovation processes in services.

\section{The dialectic motor of innovation in services}

The process model proposed here does not aim to substitute for previous models of innovation processes in services. It contributes to a clearer understanding of innovation processes in services. In fact,it describes the involvement of the dialectic motor of change, whose action has been recognized, yet not extensively researched. The construct of innovation dialectics and the process model centred on it confirm the interactive, local, multi-dimensional, unpredictable, and emergent nature of innovation processes in services as argued by Chae (2012). At the same time, the identification of innovation dialectics as one of the driving mechanisms of innovation in services supports the position of Flikkema et al. (2007) and of Edvardsson and Olsson (1996), who argue for 
the co-existence of prescribed and unplanned processes within innovation in services when multiple units of change are taken into consideration.

In addition, the dialectic model proposed here might extend what we know about service development and customer involvement because it explains what happens throughout the trial-anderror, overlapping processes that are at the centre of the practice-driven model of innovation (Edvardsson et al., 1995; Sundbo, 1997). Previous research has stressed that 'services happen’ (Martin \& Horne, 1993) and that customer involvement might increase the rate of success of innovation when dedicated methods and tools are used to cooperate and co-develop with customers and other interest groups (Ettlie \& Rosenthal, 2011; Kuusisto \& Riepula, 2011). Based on the present findings, it is here argued that not only collaborative processes, but also emerging tensions and conflicts between heterogeneous interest groups drive innovation processes in services. This entails that future studies on customer involvement should also cover non-collaborative processes to explain whether the response to tensions and conflicts between interest groups is always a trail-and-error, emergent process as the one described in innovation dialectics, or if it also has a prescribed side, such as the one suggested by Barras back in 1986. The findings from this study already suggest that innovation dialectics, as trial-and-error and emergent as it is, also entails structured and planned aspects (just as the practice-driven model of service innovation). Therefore, can service organisations control innovation dialectics at their will and monitor potential tensions and conflicts between interest groups as part of their innovation strategy?

Stage-gate models tell us that innovation in services should be formally managed, both in the case of a closed strategy and in customer involvement (e.g., Alam \& Perry, 2002; Kuusisto \& Riepula, 2011). While the dialectic model proposed here explains the function of the constructed mode of change, a reflection on innovation dialectics and the role of tensions and conflicts between different parties within the prescribed mode of change might contribute to the existing models by proposing an additional tool to drive a formalized process of innovation-expectation management. 
In addition to actively and passively involved customers (Alam, 2002, 2011, 2013; Bitner et al., 2008), it might be beneficial for innovation to constantly monitor the needs and expectations of different parties to prevent potential mismatches and be prepared to handle tensions and conflicts before they actually emerge.

\section{Conclusions}

The purpose of this study was to explore how and why tensions and conflicts between heterogeneous interest groups unfold during processes of innovation in services. Based on the inductive investigation of innovation processes in the empirical context of facility services, this paper argues that such tensions and conflicts unfold because of the mismatch between the needs and expectations of diverse interest groups, and that their resolution represents a step toward innovation. The data collected and analysed for this study suggest that tensions and conflicts are an intrinsic element of innovation in services. More interestingly, tensions and conflicts between interest groups appear to trigger the dialectic motor of change, which is why the construct of innovation dialectics is here proposed as one of the driving forces of innovation in services.

While it is not argued that innovation dialectics represent the only force behind innovation processes in services, this construct is introduced in the present paper as one of the crucial mechanisms for innovation within the service context. A dialectic model that adds a piece to the puzzle was proposed, thereby contributing to our understanding of innovation processes in services. First, this paper addressed the dialectic motor of innovation in services, as yet under-researched, by emphasizing constructed processes between multiple units of change. Second, this study explicitly focused on tensions and conflicts between heterogeneous interest groups, whereas existing literature has so far presented rather smooth processes even in the case of the involvement of different parties. Finally, the findings indicate that whether we are considering a prescribed or a constructed mode of change, and regardless of how innovation processes in services are or are not managed, the dynamics between interest groups matter in determining the actual unfolding of the process. 
Theoretically, this implies that models of innovation in services might benefit from a process approach that does not only consider the development of new service concepts, new client interfaces, new service delivery systems, and new technological options, but also the dynamics of interest group involvement and cooperation. If we accept the argument by Van de Ven and Poole (1995) that to gain a complete understanding of a specific type of change process, we need to explain all four motors and combinations thereof, scholars should be well motivated to further develop the process perspective on innovation in services. Future research should both exploit existing theories on the four motors and explore the related combinations through multiple perspectives. The work on service innovation systems by Edvardsson and colleagues, for instance, already goes in this direction. In fact, it proposes a combination of prescribed and constructive modes of change with multiple units of change, although it still does not explicitly address tensions and conflicts between interest groups. It might therefore represent a good ground for further research on the dialectic motor of innovation in services and on multiple units of change if enriched with a stronger focus on problematic dynamics such as the ones described in this paper.

On the practical side, this work is especially relevant for innovators who deal with heterogeneous networks of interest groups, such as business-to-business support service providers. Practical recommendations include a strong focus on expectation management when introducing novel services and/or changes in the network, as well as when dealing with exogenous shocks that might somehow unsettle the needs and expectations of one or more sets of interest groups. Mapping the structure of the network and the needs and expectations of the involved and potential interest groups might support the identification of potential mismatches, which in turn might prevent and/or support a smoother management of tensions and conflicts.

Nevertheless, this paper is not free of limitations. More work is required to test the robustness of the process model of innovation in services based on innovation dialectics. The database on which this study was built was rich with data until a certain degree of theoretical saturation was achieved, 
and the research design was explicitly made structured and systematic through reliable research

strategies, such as temporal bracketing. However, the results were derived from a limited sample of

service providers, and within a specific context, that is, business-to-business support services.

Further investigations are necessary to understand to what degree the model here proposed is

applicable to other service sectors and eventually to a manufacturing context.

\section{References}

Abramovici, M., \& Bancel-Charensol, L. (2004). How to take customers into consideration in service innovation projects. The Service Industries Journal, 24(1), 56-78.

Ahola, T. (2009). Efficiency in project networks : the role of inter-organizational relationships in project implementation. Teknillinen korkeakoulu.

Alam, I. (2002). An exploratory investigation of user involvement in new service development. Journal of the Academy of Marketing Science, 30(3), 250-261.

Alam, I. (2011). Process of customer interaction during new service development in an emerging country. The Service Industries Journal, 31(16), 2741-2756.

Alam, I. (2012). New service development in India's business-to-business financial services sector. Journal of Business \& Industrial Marketing, 27(3), 228-241.

Alam, I. (2013). Customer interaction in service innovation: evidence from India. International Journal of Emerging Markets, 8(1), 41-64.

Alam, I., \& Perry, C. (2002). A customer-oriented new service development process. Journal of Services Marketing, 16(6), 515-534.

Barras, R. (1990). Interactive innovation in financial and business services: The vanguard of the service revolution. Research Policy, 19(3), 215-237.

Bitner, M. J., Ostrom, A. L., \& Morgan, F. N. (2008). Service Blueprinting: A Practical Technique for Service Innovation. California Management Review, 50(3), 66-94.

Bohnsack, R., Pinkse, J., \& Kolk, A. (2014). Business models for sustainable technologies: Exploring business model evolution in the case of electric vehicles. Research Policy, 43(2), 284-300.

Busse, C., \& Wallenburg, C. (2011). Innovation management of logistics service providers. International Journal of Physical Distribution \& Logistics Management, 41(2), 187-218.

Butterfield, L. D., Borgen, W. A., Amundson, N. E., \& Erlebach, A. C. (2010). What helps and hinders workers in managing change. Journal of Employment Counseling, 47(4), 146-156.

Butterfield, L. D., Borgen, W. A., Amundson, N. E., \& Maglio, A.-S. T. (2005). Fifty years of the critical incident technique: 1954-2004 and beyond. Qualitative Research, 5(4), 475-497.

Cardellino, P., \& Finch, E. (2006). Evidence of systematic approaches to innovation in facilities management. Journal of Facilities Management, 4(3), 150-166.

Chae, B. K. (2012). An evolutionary framework for service innovation: Insights of complexity theory for service science. International Journal of Production Economics, 135(2), 813-822.

Coenen, C., Alexander, K., \& Kok, H. (2013). Facility management value dimensions from a demand perspective. Journal of Facilities Management, 11(4), 339-353.

Corbin, J. M., \& Strauss, A. L. (2008). Basics of qualitative research: techniques and procedures for developing grounded theory (3rd Editio). Sage Publications, Inc.

de Brentani, U. (1991). Success Factors in Developing New Business Services. European Journal of Marketing, 25(2), 35-59.

den Hertog, P., van der Aa, W., \& De Jong, M. W. (2010). Capabilities for managing service innovation: towards a conceptual framework. Journal of Service Management, 21(4), 490-514.

Drejer, I. (2004). Identifying innovation in surveys of services: a Schumpeterian perspective. Research Policy, 33(3), $551-562$. 
Drori, I., \& Honig, B. (2013). A Process Model of Internal and External Legitimacy. Organization Studies, 34(3), 345376.

Edvardsson, B., Haglund, L., \& Mattson, J. (1995). Analysis, planning, improvisation and control in the development of new services. International Journal of Service Industry Management, 6(2), 24-35.

Edvardsson, B., \& Olsson, J. (1996). Key Concepts for New Service Development. The Service Industries Journal, 16(2), 140-164.

Eisenhardt, K. M. (1989). Building theories from case study research. Academy of Management Review, 14(4), 532-550.

Eisenhardt, K. M., \& Bourgeois, L. J. (1988). Politics of strategic decision making in high-velocity environments: toward a mid-range theory. Academy of Management Journal, 31(4), 737-770.

Erez, M., Jarvenpaa, S., Lewis, M. W., Smith, W. K., \& Tracey, P. (2013). Paradox, Tensions and Dualities of Innovation and Change. Organization Studies, 34(10), 1575-1578.

Ettlie, J. E., \& Rosenthal, S. R. (2011). Service versus Manufacturing Innovation. Journal of Product Innovation Management, 28(2), 285-299.

Fitzsimmons, J. A., \& Fitzsimmons, M. J. (2006). Service management: operations, strategy, and information technology. McGraw-Hill/Irwin.

Flikkema, M., Jansen, P., \& Van Der Sluis, L. (2007). Identifying neo-Schumpeterian innovation in service firms: A conceptual essay with a novel classification. Economics of Innovation and New Technology, 16(7), 541-558.

Fuglsang, L., Sundbo, J., \& Sørensen, F. (2011). Dynamics of experience service innovation: innovation as a guided activity - results from a Danish survey. The Service Industries Journal, 31(5), 661-677.

Gallouj, F., \& Weinstein, O. (1997). Innovation in services. Research Policy, 26(4-5), 537-556.

Geels, F. W. (2002). Technological transitions as evolutionary reconfiguration processes: a multi-level perspective and a case-study. Research Policy, 31(8-9), 1257-1274.

Glaser, B. G., \& Strauss, A. L. (2009). The Discovery of Grounded Theory: Strategies for Qualitative Research (7th editio). Transactions Publishers.

Goyal, S., \& Pitt, M. (2007). Determining the role of innovation management in facilities management. Facilities, 25(1/2), 48-60.

Gremler, D. D. (2004). The Critical Incident Technique in Service Research. Journal of Service Research, 7(1), 65-89.

Guerard, S., Bode, C., \& Gustafsson, R. (2013). Turning Point Mechanisms in a Dualistic Process Model of Institutional Emergence: The Case of the Diesel Particulate Filter in Germany. Organization Studies, 34(5-6), 781-822.

Jensen, P. A. (2008). The origin and constitution of facilities management as an integrated corporate function. Facilities, 26(13/14), 490-500.

Jensen, P. A., van der Voordt, T. J. M., Coenen, C., von Felten, D., Lindholm, A.-L., Nielsen, S. B., ... Pfenninger, M. (2012). In search for the added value of FM: what we know and what we need to learn. Facilities, 30(5/6), 199217.

Johne, F. A., \& Storey, C. (1998). New service development: a review of the literature and annotated bibliography. European Journal of Marketing, 32(3), 184-251.

Klarner, P., \& Raisch, S. (2012). Move to the Beat-Rhythms of Change and Firm Performance. Academy of Management Journal, 56(1), 160-184.

Kuusisto, A., \& Riepula, M. (2009). Customer Interaction and Service Innovation Performance: A Checklist for Service Innovators. 2009 International Conference on Information Management, Innovation Management and Industrial Engineering, (Tether), 318-321.

Kuusisto, A., \& Riepula, M. M. (2011). Customer interaction in service innovation: seldom intensive but often decisive. Case studies in three business sectors. International Journal of Technology Management, 55(1/2), 171-186.

Langley, A. (1999). Strategies for theorizing from process data. Academy of Management Review, 24(4), 691-710.

Langley, A., Smallman, C., Tsoukas, H., \& Van de Ven, A. H. (2013). Process Studies of Change in Organization and Management: Unveiling Temporality, Activity, and Flow. Academy of Management Journal, 56(1), 1-13.

Lee, A. S., \& Baskerville, R. L. (2003). Generalizing Generalizability in Information Systems Research. Information Systems Research, 14(3), 221-243.

Lehoux, P., Daudelin, G., Williams-Jones, B., Denis, J.-L., \& Longo, C. (2014). How do business model and health technology design influence each other? Insights from a longitudinal case study of three academic spin-offs. Research Policy, 43(6), 1025-1038.

Lewis, M. W. (2000). Exploring paradox: toward a more comprehensive guide. Academy of Management Review, 25(4), $760-776$. 
Martin, C. R., \& Horne, D. A. (1993). Services innovation: successful versus unsuccessful firms. International Journal of Service Industry Management, 4(1), 49-65.

Matthing, J., Sandén, B., \& Edvardsson, B. (2004). New service development: Learning from and with customers. International Journal of Service Industry Management, 15(5), 479-498.

Melton, H. L., \& Hartline, M. D. (2010). Customer and Frontline Employee Influence on New Service Development Performance. Journal of Service Research, 13(4), 411-425.

Miles, I. (2008). Patterns of innovation in service industries. IBM Systems Journal, 47(1), 115-128.

Miles, M. B., \& Huberman, M. A. (1994). Qualitative data analysis: An expanded sourcebook (II). Thousand Oaks, California: Sage Publications.

Mills, P. K., \& Margulies, N. (1980). Toward a Core Typology of Service Organizations. Academy of Management Review, 5(2), 255-266.

Mota Pedrosa, A. (2012). Customer Integration during Innovation Development: An Exploratory Study in the Logistics Service Industry. Creativity and Innovation Management, 21(3), 263-276.

Mudrak, T., Van Wagenberg, A., \& Wubben, E. (2005). Innovation process and innovativeness of facility management organizations. Facilities, 23(3/4), 103-118.

Noor, M. N. M., \& Pitt, M. (2009). The application of supply chain management and collaborative innovation in the delivery of facilities management services. Journal of Facilities Management, 7(4), 283-297.

Novozymes. (2013). The Novozymes Report 2013 - The year in brief. Retrieved March 27, 2014, from http://report2013.novozymes.com/

Nutt, B. (2000). Four competing futures for facility management. Facilities, 18(3/4), 124-132.

Ordanini, A., \& Maglio, P. P. (2009). Market Orientation, Internal Process, and External Network: A Qualitative Comparative Analysis of Key Decisional Alternatives in the New Service Development. Decision Sciences, 40(3), 601-625.

Ottenbacher, M., Shaw, V., \& Ermen, D. (2006). The new service development process in successful small entrepreneurial firms. The International Journal of Entrepreneurship and Innovation, 7(2), 77-85.

Pitt, M., \& Tucker, M. (2008). Performance measurement in facilities management: driving innovation? Property Management, 26(4), 241-254.

Poole, M. S., Van de Ven, A. H., Dooley, K., \& Holmes, M. E. (2000). Organizational Change and Innovation Processes: Theory and Methods for Research. Oxford University Press.

Rasche, A., \& Chia, R. (2009). Researching Strategy Practices: A Genealogical Social Theory Perspective. Organization Studies, 30(7), 713-734.

Scheuing, E. E., \& Johnson, E. M. (1989). A proposed model for New Service Development. Journal of Services Marketing, 3(2), 25-34.

Sjödin, C., \& Kristensson, P. (2012). Customers' experiences of co-creation during service innovation. International Journal of Quality and Service Sciences, 4(2), 189-204.

Specht, N., Fichtel, S., \& Meyer, A. (2007). Perception and attribution of employees' effort and abilities: The impact on customer encounter satisfaction. International Journal of Service Industry Management, 18(5), 534-554.

Sundbo, J. (1997). Management of Innovation in Services. The Service Industries Journal, 17(3), 432-455.

Teece, D. J. (2010). Business Models, Business Strategy and Innovation. Long Range Planning, 43(2-3), $172-194$.

Van de Ven, A. H., \& Poole, M. S. (1995). Explaining development and change in organizations. Academy of Management Review, 20(3), 510-540.

Van de Ven, A. H., \& Poole, M. S. (2005). Alternative approaches for studying organizational change. Organization Studies, 26(9), 1377-1404.

van Dijk, S., Berends, H., Jelinek, M., Romme, A. G. L., \& Weggeman, M. (2011). Micro-Institutional Affordances and Strategies of Radical Innovation. Organization Studies, 32(11), 1485-1513.

Webster, J., \& Watson, R. T. (2002). Analyzing the past to prepare for the future: Writing a literature review. MIS Quarterly, 26(2), xiii-xxiii.

Yin, R. K. (2009). Case study research: design and methods. Sage Publications. 
Tables (captions below tables)

Table 1

\begin{tabular}{|c|c|c|c|c|}
\hline & Time span & & Sources of data & \\
\hline $\begin{array}{l}\text { Explorative } \\
\text { study }\end{array}$ & 2011-2013 & $\begin{array}{l}16 \text { semi-structured in- } \\
\text { depth interviews and } \\
\text { interview reports }\end{array}$ & $\begin{array}{l}\text { Archive data (company Specialised facility } \\
\begin{array}{ll}\text { owned and publicly } & \text { service academic and } \\
\text { available) } & \text { popular literature }\end{array}\end{array}$ & $\begin{array}{ll}\begin{array}{l}\text { Passive observation of } \\
\text { workshops and }\end{array} & \text { and motes } \\
\text { conferences } & \\
\end{array}$ \\
\hline $\begin{array}{l}\text { Longitudinal } \\
\text { case study }\end{array}$ & $\begin{array}{l}2000-2013 \\
\text { Data } \\
\text { collected } \\
\text { 2011-2013 }\end{array}$ & $\begin{array}{l}7 \text { semi-structured in- } \\
\text { depth interviews and } \\
\text { interview reports }\end{array}$ & $\begin{array}{l}\text { Archive data (company Field notes and memos } \\
\text { owned and publicly } \\
\text { available) }\end{array}$ & \\
\hline
\end{tabular}

Table 1: Data collection sources 
Table 2

\begin{tabular}{|c|c|c|c|c|c|}
\hline & \multicolumn{4}{|c|}{$\begin{array}{l}\text { 2000-2013 INNOVATION PROCESSES AND TENSIONS } \\
\text { BETWEEN INTEREST GROUPS }\end{array}$} & \multirow{2}{*}{\begin{tabular}{l}
\multicolumn{1}{c}{ ZOOM IN } \\
$\begin{array}{l}\text { Single service } \\
\text { innovations }\end{array}$
\end{tabular}} \\
\hline & Period I & Period II & Period III & Period IV & \\
\hline & $\begin{array}{l}\text { Demerger } \\
\text { Crisis }\end{array}$ & $\begin{array}{l}\text { Financial } \\
\text { Crisis }\end{array}$ & Global shift & $\begin{array}{l}\text { Organisational } \\
\text { change }\end{array}$ & \\
\hline $\begin{array}{l}\text { Triggering } \\
\text { change } \\
\text { incident }\end{array}$ & $\begin{array}{l}\text { Endogenous } \\
\text { change: } \\
\text { demerger of } \\
\text { NZ from } \\
\text { mother } \\
\text { company }\end{array}$ & $\begin{array}{l}\text { Exogenous } \\
\text { change: } \\
\text { emergence and } \\
\text { impact of } \\
\text { financial crisis } \\
\text { on Danish } \\
\text { economy and } \\
\text { consequently } \\
\mathrm{NZ}\end{array}$ & $\begin{array}{l}\text { Endogenous } \\
\text { change: } \\
\text { decision to } \\
\text { centralize and } \\
\text { globalize } \\
\text { facility service } \\
\text { provision }\end{array}$ & $\begin{array}{l}\text { Exogenous } \\
\text { change: new } \\
\text { CEO } \\
\text { implementing } \\
\text { significant } \\
\text { organisational } \\
\text { changes with } \\
\text { both short- and } \\
\text { long-term } \\
\text { consequences } \\
\end{array}$ & $\begin{array}{l}\text { Endogenous } \\
\text { change and/or } \\
\text { exogenous } \\
\text { shock }\end{array}$ \\
\hline $\begin{array}{l}\text { Emergent } \\
\text { issue }\end{array}$ & $\begin{array}{l}\text { How should } \\
\text { facility } \\
\text { services be } \\
\text { managed? }\end{array}$ & $\begin{array}{l}\text { How can } \\
\text { facility service } \\
\text { provision be } \\
\text { more cost } \\
\text { efficient } \\
\text { without } \\
\text { compromising } \\
\text { the } \\
\text { implementatio } \\
n \text { of core } \\
\text { business } \\
\text { activities? }\end{array}$ & $\begin{array}{l}\text { How can we } \\
\text { manage } \\
\text { facility } \\
\text { services with a } \\
\text { centralized } \\
\text { and global } \\
\text { organisation? }\end{array}$ & $\begin{array}{l}\text { How can we } \\
\text { provide } \\
\text { facility } \\
\text { services given } \\
\text { the new } \\
\text { organisational } \\
\text { setting? }\end{array}$ & $\begin{array}{l}\text { How can the } \\
\text { match between } \\
\text { needs and } \\
\text { expectations of } \\
\text { heterogeneous } \\
\text { interest groups } \\
\text { be ensured } \\
\text { when } \\
\text { developing } \\
\text { new services } \\
\text { or improving } \\
\text { existing ones? }\end{array}$ \\
\hline Thesis & $\begin{array}{l}\text { NZ FM: More } \\
\text { cost } \\
\text { competitivenes } \\
\text { s and better } \\
\text { services than } \\
\text { before the } \\
\text { demerger }\end{array}$ & $\begin{array}{l}\text { NZ: Lower } \\
\text { budget for } \\
\text { facility } \\
\text { services } \\
\end{array}$ & $\begin{array}{l}\text { NZ FM: } \\
\text { Centralized } \\
\text { and global } \\
\text { facility service } \\
\text { management }\end{array}$ & $\begin{array}{l}\text { NZ and NZ } \\
\text { FM: Strong } \\
\text { efficiency and } \\
\text { global } \\
\text { standards }\end{array}$ & $\begin{array}{l}\text { Needs and } \\
\text { expectations } \\
\text { of one (or } \\
\text { more) sets of } \\
\text { interest groups }\end{array}$ \\
\hline Antithesis & $\begin{array}{l}\text { External } \\
\text { provider: } \\
\text { Same } \\
\text { conditions as } \\
\text { before the } \\
\text { demerger } \\
\end{array}$ & $\begin{array}{l}\text { NZ } \\
\text { employees: } \\
\text { High level } \\
\text { facility } \\
\text { services } \\
\end{array}$ & $\begin{array}{l}\text { Local NZ FM } \\
\text { managers: } \\
\text { local facility } \\
\text { service } \\
\text { management } \\
\end{array}$ & $\begin{array}{l}\text { NZ } \\
\text { employees: } \\
\text { Individual, } \\
\text { local and } \\
\text { cultural } \\
\text { differences } \\
\end{array}$ & $\begin{array}{l}\text { Needs and } \\
\text { expectations } \\
\text { of other set(s) } \\
\text { of interest } \\
\text { groups }\end{array}$ \\
\hline Conflict & $\begin{array}{l}\text { NZ and NZ } \\
\text { FM vs. } \\
\text { External } \\
\text { provider } \\
\end{array}$ & $\begin{array}{l}\text { NZ vs. NZ } \\
\text { employees }\end{array}$ & $\begin{array}{l}\text { Headquarter } \\
\text { NZ FM vs. } \\
\text { Local FM } \\
\text { managers } \\
\end{array}$ & $\begin{array}{l}\text { NZ and NZ } \\
\text { FM vs. NZ } \\
\text { employees }\end{array}$ & $\begin{array}{l}\text { Unbalanced } \\
\text { needs and } \\
\text { expectations }\end{array}$ \\
\hline Synthesis & $\begin{array}{l}\text { Discontinued } \\
\text { contract with } \\
\text { external } \\
\text { provider } \\
\end{array}$ & $\begin{array}{l}\text { New travel } \\
\text { policy and } \\
\text { video- } \\
\text { conference } \\
\text { facilities } \\
\text { (among other } \\
\text { solutions) } \\
\end{array}$ & $\begin{array}{l}\text { Creation of } \\
\text { GFM team to } \\
\text { find balance } \\
\text { between } \\
\text { specialization } \\
\text { and } \\
\text { standardizatio } \\
\text { n of facility } \\
\text { services on } \\
\text { global scale } \\
\end{array}$ & $\begin{array}{l}\text { Separated yet } \\
\text { parallel } \\
\text { management } \\
\text { of facility } \\
\text { services in } \\
\text { Denmark and } \\
\text { in the ROTW }\end{array}$ & $\begin{array}{l}\text { New service } \\
\text { and/or } \\
\text { improved } \\
\text { service } \\
\end{array}$ \\
\hline $\begin{array}{l}\text { Major } \\
\text { innovation } \\
\text { outcome(s) }\end{array}$ & $\begin{array}{l}\text { New client } \\
\text { interface } \\
\text { (including new } \\
\text { external } \\
\text { providers) } \\
\end{array}$ & $\begin{array}{l}\text { New } \\
\text { technological } \\
\text { options }\end{array}$ & $\begin{array}{l}\text { New service } \\
\text { delivery } \\
\text { system }\end{array}$ & $\begin{array}{l}\text { New service } \\
\text { delivery } \\
\text { system }\end{array}$ & $\begin{array}{l}\text { New service } \\
\text { concept; new } \\
\text { client } \\
\text { interface; new } \\
\text { service } \\
\text { delivery } \\
\text { system; new } \\
\text { technological } \\
\text { option(s) } \\
\end{array}$ \\
\hline
\end{tabular}




\begin{tabular}{|c|c|c|c|c|c|}
\hline & NZ & $\begin{array}{l}\text { Higher cost } \\
\text { competitivenes } \\
\text { S }\end{array}$ & $\begin{array}{l}\text { Lower } \\
\text { resources to } \\
\text { allocate to } \\
\text { facility } \\
\text { services }\end{array}$ & $\begin{array}{l}\text { Increased } \\
\text { transparency }\end{array}$ & $\begin{array}{l}\text { Improved } \\
\text { global facility } \\
\text { service } \\
\text { provision }\end{array}$ \\
\hline & NZ FM & $\begin{array}{l}\text { Better } \\
\text { agreement and } \\
\text { partnership- } \\
\text { like } \\
\text { relationship } \\
\text { with new } \\
\text { external } \\
\text { providers }\end{array}$ & $\begin{array}{l}\text { Increased } \\
\text { responsibilities } \\
\text { in terms of } \\
\text { strategic cost } \\
\text { reduction } \\
\text { management }\end{array}$ & $\begin{array}{l}\text { Global } \\
\text { responsibilities }\end{array}$ & $\begin{array}{l}\text { Separation of } \\
\text { strategic } \\
\text { responsibilities } \\
\text { (DK FM) and } \\
\text { operational } \\
\text { responsibilities } \\
\text { (ROTW FM) }\end{array}$ \\
\hline & $\begin{array}{l}\text { NZ } \\
\text { employees }\end{array}$ & $\begin{array}{l}\text { Different } \\
\text { client } \\
\text { interface, e.g., } \\
\text { new } \\
\text { employees of } \\
\text { external } \\
\text { provider to } \\
\text { deal with and } \\
\text { different } \\
\text { standards }\end{array}$ & $\begin{array}{l}\text { New } \\
\text { perception of } \\
\text { support } \\
\text { service } \\
\text { consumption } \\
\text { (higher } \\
\text { awareness of } \\
\text { support } \\
\text { service costs) }\end{array}$ & $\begin{array}{l}\text { Different } \\
\text { standards for } \\
\text { certain facility } \\
\text { service } \\
\text { features }\end{array}$ & $\begin{array}{l}\text { New services } \\
\text { and different, } \\
\text { global-based } \\
\text { standards for } \\
\text { existing } \\
\text { services }\end{array}$ \\
\hline $\begin{array}{l}\text { Impact on } \\
\text { interest } \\
\text { groups }\end{array}$ & $\begin{array}{l}\text { External } \\
\text { providers }\end{array}$ & $\begin{array}{l}\text { (New } \\
\text { providers): } \\
\text { Partnership- } \\
\text { like } \\
\text { relationship } \\
\text { with internal } \\
\text { provider }\end{array}$ & $\begin{array}{l}\text { New } \\
\text { expectations } \\
\text { from NZ and } \\
\text { NZ FM to } \\
\text { support cost } \\
\text { savings }\end{array}$ & $\begin{array}{l}\text { Not involved } \\
\text { (agreements } \\
\text { still local) }\end{array}$ & $\begin{array}{l}\text { Global } \\
\text { agreements } \\
\text { (for some } \\
\text { providers) }\end{array}$ \\
\hline
\end{tabular}

Table 2: Integrative summary of findings. 


\section{Figures:}

Figure 1: Typology of process theories (Adapted from Van de Ven and Poole, 1995).

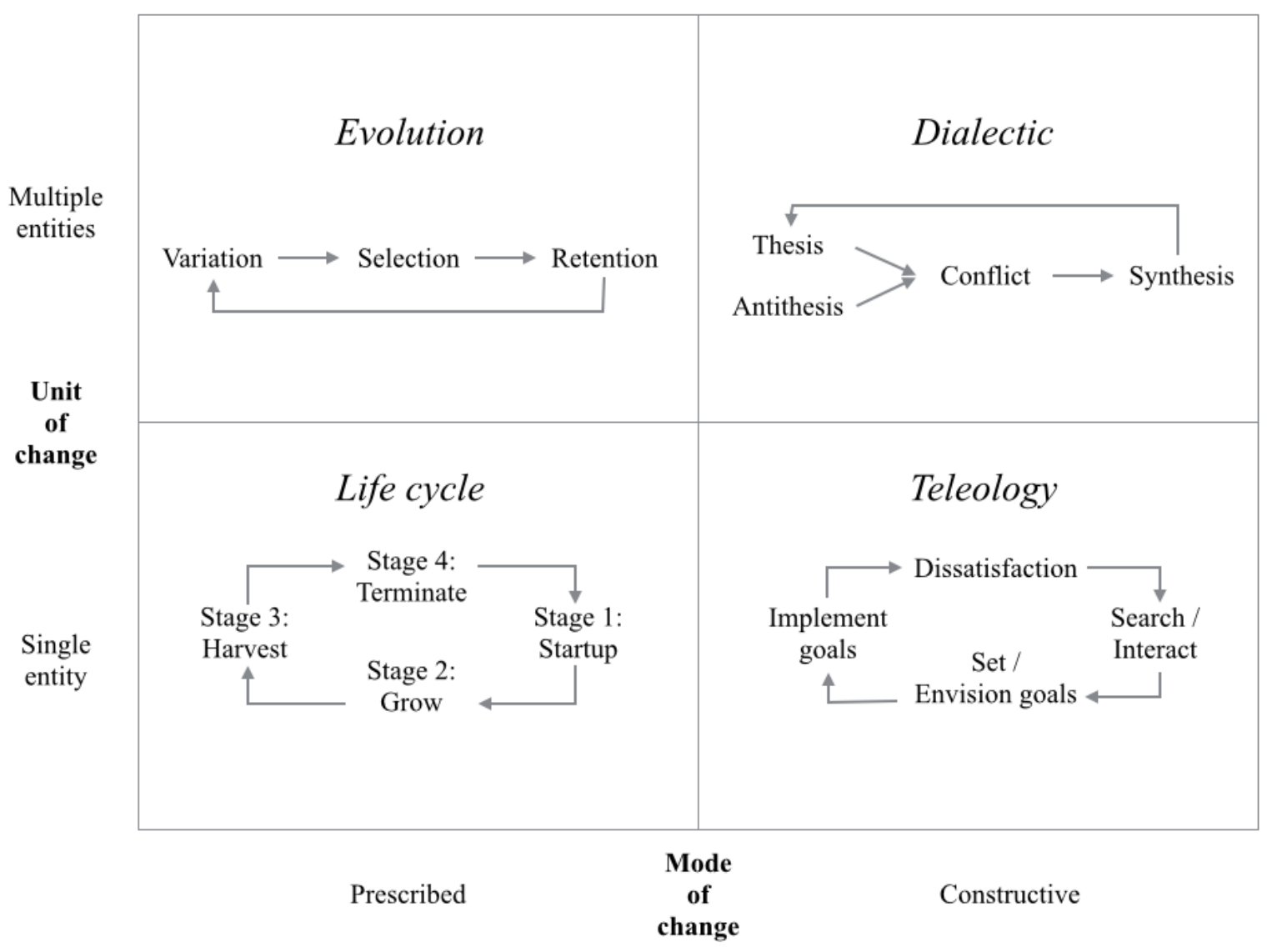

Figure 2: Innovation dialectics: a dialectic driver of innovation in services. 
Exogenous shock

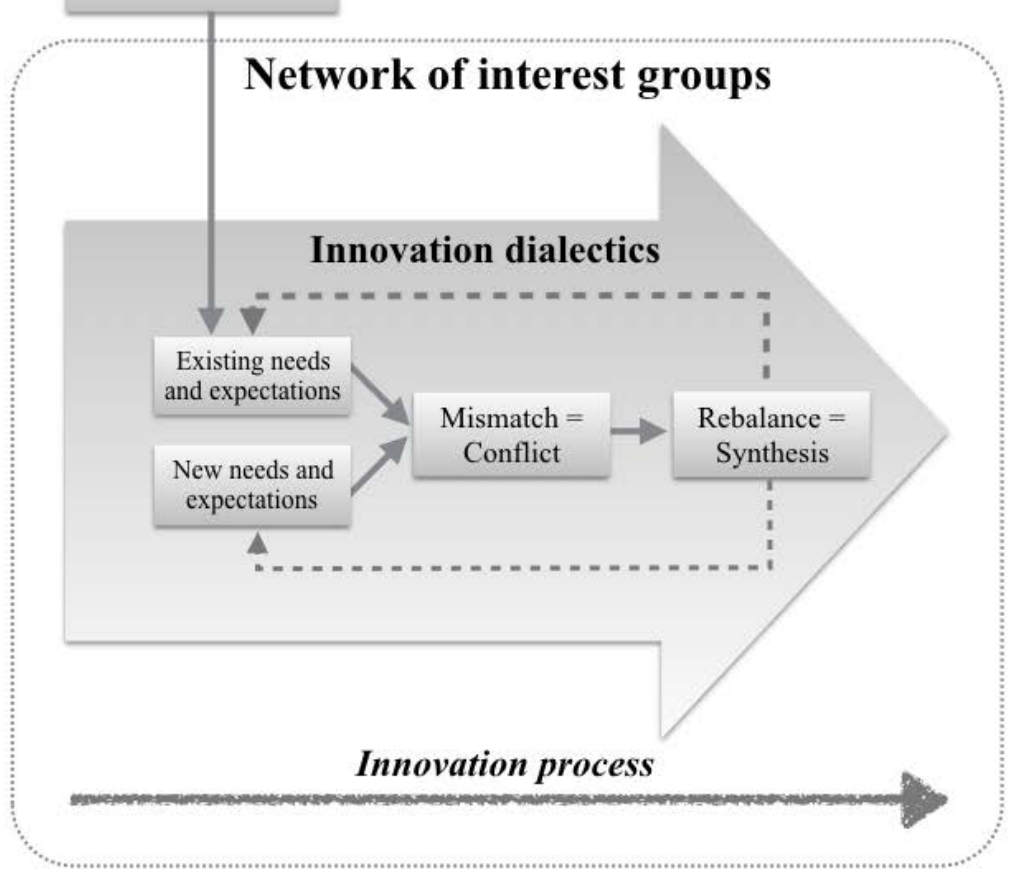

